\title{
PENGARUH OKSITOSIN TERHADAP KONTRAKSI OTOT POLOS UTERUS
}

\author{
Risma Aprinda Kristanti \\ Jurusan Biologi, Fakultas Sains dan Teknologi \\ Universitas Islam Negeri (UIN) Maulana Malik Ibrahim Malang \\ Email: risma.aprinda@yahoo.com
}

\begin{abstract}
ABSTRAK
Stimulus yang memicu sebagian besar kontraksi otot polos adalah adanya peningkatan ion kalsium intra sel. Peningkatan ini dapat ditimbulkan pada jenis otot polos yang berbeda oleh perangsangan saraf pada serabut otot polos, stimulasi hormon, regangan serabut, atau bahkan perubahan pada lingkungan kimiawi serabut. Suatu hormon dapat menimbulkan kontraksi otot polos bila membran sel otot mengandung reseptor perangsang bergerbang hormon untuk hormon tertentu. Beberapa reseptor hormon pada membran otot polos akan membuka kanal ion kalsium dan natrium serta menimbulkan depolarisasi membran. Kadang timbul potensial aksi, atau justru mungkin memperkuat potensial aksi yang telah terjadi. Pada keadaan lain, terjadi depolarisasi tanpa disertai dengan potensial aksi, dan depolarisasi ini membuat ion kalsium masuk ke dalam sel sehingga terjadi kontraksi. Oksitosin merangsang kontraksi uterus melalui mekanisme $\mathrm{Ca}^{2+}$ dependent dan $\mathrm{Ca}^{2+}$ independent. Pada jalur $\mathrm{Ca}^{2+}$ dependent, beberapa reseptor hormon pada membran otot polos akan membuka kanal ion kalsium dan natrium serta menimbulkan depolarisasi membran. Jalur $\mathrm{Ca}^{2+}$ independent adalah dengan melalui jalur Rho kinase. Rho yang telah teraktivasi meningkatkan fosforilasi rantai ringan miosin pada konsentrasi kalsium yang konstan, ini menunjukkan bahwa Rho memiliki peran pada mekanisme pengaturan " $\mathrm{Ca}^{2+}$ sensitization"

Kata kunci : oksitosin, kontraksi, uterus, kalsium, Rho
\end{abstract}

\section{PENDAHULUAN}

Otot polos mempunyai beragam cara dalam mencetuskan kontraksi atau relaksasi sebagai respon terhadap hormon, neurotransmitter, dan substansi lain yang berbeda (Guyton C \& Hall JE, 2006).

Suatu hormon dapat menimbulkan kontraksi otot polos bila membran sel otot mengandung reseptor perangsang bergerbang hormon untuk hormon tertentu. Sebaliknya hormon akan menimbulkan inhibisi jika membran mengandung reseptor penghambat untuk hormon tersebut daripada mengandung reseptor perangsang (Guyton C \& Hall, JE, 2006).

Hormon oksitosin, sesuai dengan namanya, sangat kuat merangsang uterus yang hamil, terutama pada akhir kehamilan. Oleh karena itu banyak ahli kebidanan yang meyakini bahwa hormon ini berperan dalam persalinan bayi (Guyton C \& Hall JE, 2006). Oksitosin merangsang kontraksi uterus melalui mekanisme $\mathrm{Ca}^{2+}$ dependent dan $\mathrm{Ca}^{2+}$ independent. Oksitosin tidak hanya memicu pengeluaran $\mathrm{Ca}^{2+}$ intraseluler, tetapi juga meningkatkan aktivitas $\mathrm{Ca}^{2+}$ terhadap uterus melalui mekanisme yang melibatkan G-protein. (Tahara $\mathrm{M}$ et al, 2002)

\section{KONTRAKSI OTOT POLOS}

Stimulus yang memicu sebagian besar kontraksi otot polos adalah adanya peningkatan ion kalsium intra sel. Peningkatan ini dapat ditimbulkan pada jenis otot polos yang berbeda oleh perangsangan saraf pada serabut otot polos, 
stimulasi hormon, regangan serabut, atau bahkan perubahan pada lingkungan kimiawi serabut. (Guyton C \& Hall JE, 2006)

Tetapi otot polos tidak mengandung troponin, yaitu protein pengatur yang diaktifkan oleh ion kalsium, untuk menimbulkan kontraksi otot rangka. Sebagai pengganti troponin, sel-sel otot polos mengandung sejumlah besar protein pengatur lain yang disebut kalmodulin. Walaupun protein ini serupa dengan troponin, kalmodulin mempunyai cara yang berbeda dalam memicu kontraksi. Kalmodulin melakukan hal ini dengan mengaktifkan jembatan silang miosin. Proses aktivasi ini dan kontraksi selanjutnya terjadi dalam urutan sebagai berikut : (1) Ion kalsium berikatan dengan kalmodulin, (2) Kombinasi kalmodulin-ion kalsium kemudian bergabung dengan sekaligus mengaktifkan miosin kinase, yaitu suatu enzim yang melakukan fosforilasi, (3) Salah satu rantai ringan dalam setiap kepala miosin yang disebut rantai pengatur, mengalami fosforilasi sebagai respon terhadap miosin kinase. Bila rantai ini tidak mengalami fosforilasi, siklus pelekatan-pelepasan kepala miosin dengan filamen aktin tidak akan terjadi. Tetapi bila rantai pengatur mengalami fosforilasi, kepala miosin memiliki kemampuan untuk berikatan secara berulang dengan filamen aktin dan bekerja melalui seluruh proses siklus "tarikan" berkala (Guyton C \& Hall JE, 2006).

Bila konsentrasi ion kalsium menurun di bawah nilai kritis, proses yang telah disebutkan di atas akan berlangsung terbalik secara otomatis, kecuali untuk fosforilasi kepala miosin. Pembalikan proses ini membutuhkan enzim lain, yaitu miosin fosfatase, yang terletak di dalam cairan pada sel otot polos, yang menguraikan fosfat dari rantai ringan pengatur. Kemudian siklus berhenti dan kontraksi berakhir (Guyton C \& Hall JE, 2006).
PENGARUH HORMON TERHADAP KONTRAKSI OTOT POLOS

Suatu hormon dapat menimbulkan kontraksi otot polos bila membran sel otot mengandung reseptor perangsang bergerbang hormon untuk hormon tertentu. Sebaliknya hormon akan menimbulkan inhibisi jika membran mengandung reseptor penghambat untuk hormon tersebut daripada mengandung reseptor perangsang (Guyton C \& Hall JE, 2006).

Beberapa reseptor hormon pada membran otot polos akan membuka kanal ion kalsium dan natrium serta menimbulkan depolarisasi membran. Kadang timbul potensial aksi, atau justru mungkin memperkuat potensial aksi yang telah terjadi. Pada keadaan lain, terjadi depolarisasi tanpa disertai dengan potensial aksi, dan depolarisasi ini membuat ion kalsium masuk ke dalam sel sehingga terjadi kontraksi (Guyton C \& Hall JE, 2006).

\section{OKSITOSIN}

\section{Sebagian besar hormon yang} bersirkulasi dalam tubuh akan mempengaruhi kontraksi otot polos hingga derajat tertentu, dan beberapa diantaranya mempunyai pengaruh yang sangat besar. Diantara hormon dalam darah yang penting tersebut adalah norepinefrin, epinefrin, asetilkolin, angiotensin, endothelin, vasopressin, oksitosin, serotonin, dan histamine (Guyton C \& Hall JE, 2006).

Oksitosin adalah neuropeptida yang terdiri dari sembilan asam amino, disintesis oleh neuron-neuron magnoseluler pada supraoptik dan paraventrikular hipotalamus. Oksitosin dibebaskan menuju sirkulasi melaui proses eksositosis dari pituitary posterior dan terminal saraf sebagai respon terhadap berbagai rangsang (Vrachnis N et al, 2012).

Oksitosin merupakan suatu hormon yang disekresikan oleh neurohipofisis yang secara khusus menyebabkan kontraksi uterus. Oksitosin meningkatkan kontraksi otot polos melalui mekanisme: (1) otot uterus meningkatkan jumlah reseptor- 
reseptor oksitosin sehingga meningkatkan responnya terhadap dosis oksitosin yang diberikan selama beberapa bulan kehamilan, (2) Kecepatan sekresi oksitosin oleh neurohipofisis sangat meningkat pada

saat persalinan, (3) Pada hewan yang mengalami hipofisektomi masih dapat melahirkan bayinya pada kehamilan aterm, persalinannya akan berlangsung lama, (4) Iritasi atau regangan pada serviks uteri, seperti yang terjadi selama persalinan, dapat menyebabkan sebuah refleks neurogenik melalui nucleus paraventrikular dan supraoptik hipotalamus yang dapat menyebabkan kelenjar neurohipofisis meningkatkan sekresi oksitosinnya (Guyton C \& Hall JE, 2006).

\section{PENGARUH OKSITOSIN TERHADAP KONTRAKSI OTOT POLOS UTERUS}

Hormon oksitosin, sesuai dengan namanya, sangat kuat merangsang uterus yang hamil, terutama pada akhir kehamilan. Oleh karena itu banyak ahli kebidanan yang meyakini bahwa hormon ini berperan dalam persalinan bayi (Guyton C \& Hall JE, 2006). Oksitosin tidak hanya memicu pengeluaran $\mathrm{Ca}^{2+}$ intraseluler, tetapi juga meningkatkan aktivitas $\mathrm{Ca}^{2+}$ terhadap uterus melalui mekanisme yang melibatkan G-protein (Tahara M et al, 2002).

Faktor-faktor yang menentukan pengaruh oksitosin terhadap kontraksi uterus adalah kadar reseptor, desensitisasi reseptor, dan produksi oksitosin lokal (Vrachnis $\mathrm{N}$ et al, 2011). Oksitosin merangsang kontraksi uterus melalui mekanisme $\mathrm{Ca}^{2+}$ dependent dan $\mathrm{Ca}^{2+}$ independent. Jalur $\mathrm{Ca}^{2+}$ independent adalah dengan melalui jalur Rho kinase (Tahara $\mathrm{M}$ et al, 2002).

\section{$\mathrm{Ca}^{2+}$ Dependent}

Beberapa reseptor hormon pada membran otot polos akan membuka kanal ion kalsium dan natrium serta menimbulkan depolarisasi membran. Kadang timbul potensial aksi, atau justru makin memperkuat potensial aksi yang telah terjadi. Pada keadaan lain, terjadi depolarisasi tanpa disertai dengan potensial aksi, dan depolarisasi ini membuat ion kalsium masuk ke dalam sel sehingga terjadi kontraksi (Guyton C \& Hall JE, 2006).

Kadang kontraksi otot polos dicetuskan oleh hormon tanpa secara langsung menyebabkan perubahan pada potensial membran. Pada keadaan ini, hormon dapat mengaktifkan suatu reseptor membran yang tidak membuka kanal ion manapun namun justru menyebabkan perubahan internal pada serabut otot, seperti pelepasan ion kalsium dari retikulum sarkoplasma intrasel, ion kalsium kemudian menginduksi terjadinya kontraksi (Guyton C \& Hall JE, 2006).

Oksitosin hanya memiliki satu reseptor, yang termasuk dalam klas $1 \mathrm{G}$ protein, tipe rodopsin. Gen untuk reseptor oksitosin terletak pada kromosom 3p25, mengandung tiga intron dan empat ekson. Permukaan membran sel mengalami aktivasi setelah reseptor oksitosin berikatan dengan molekul oksitosin, kemudian reseptor tersebut akan menyebabkan aktivasi berbagai macam jalur signal intraseluler, sehingga menghasilkan beberapa efek dari kerja hormon, termasuk kontraksi. Reseptor oksitosin berpasangan dengan Gq/11a, dari golongan GTP binding protein. Pengikatan oksitosin melalui Gaq/11, fosfolipase C(PLC) yang menghidrolisis fosfatidilinositol 4,5bifosfat (PIP2) menjadi inositol 1,4,5trifosfat (IP3) dan diasilgliserol (DAG). IP3 menyebabkan ion-ion kalsium keluar dari depo intraseluler, sedangkan DAG mengaktivasi protein kinase tipe C (PKC), yang kemudian memfosforilasi protein lain. Keluarnya ion-ion kalsium dari depo intraseluler menyebabkan kalsium berikatan dengan kalmodulin dan mengaktifkan fosforilasi rantai ringan miosin sehingga menyebabkan otot uterus berkontraksi (Vrachnis N et al, 2012) 


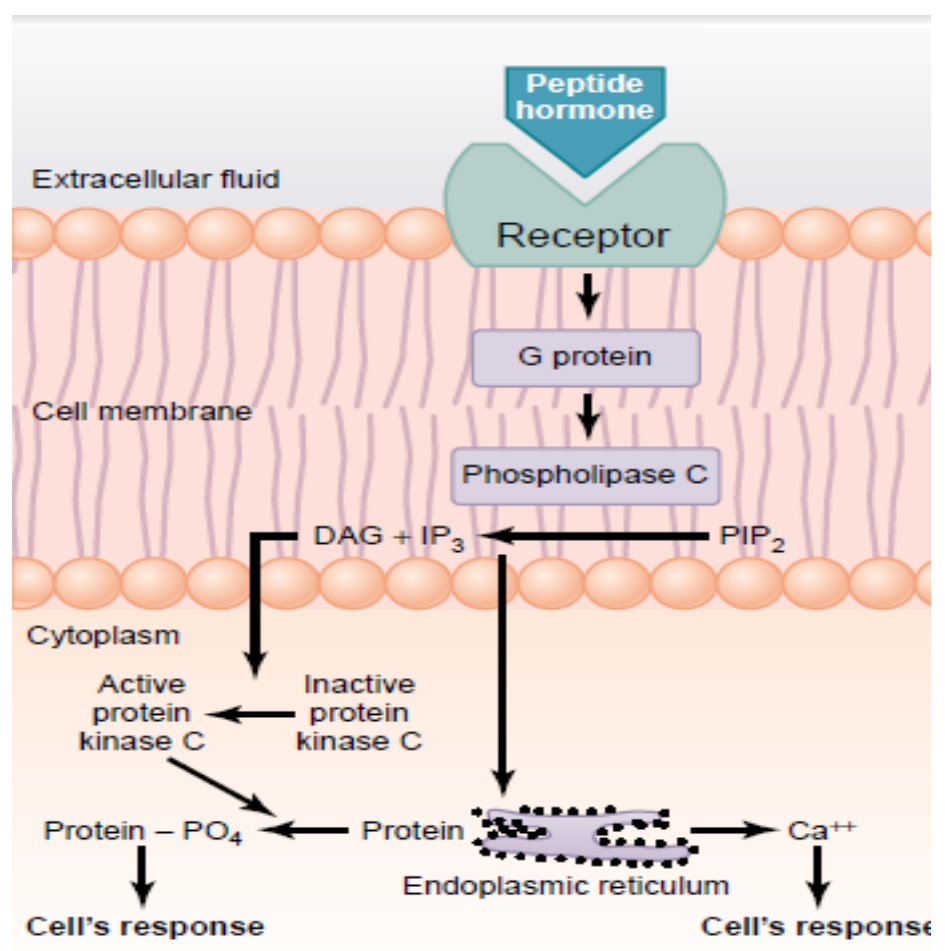

Gambar 1. Mekanisme $\mathrm{Ca}^{2+}$ Dependent Oksitosin

\section{$\mathrm{Ca}^{2+}$ Independent}

Reseptor oksitosin mengaktivasi mitogen activated protein kinase (MAPK) dan jalur Rho kinase. Aktivasi reseptor oksitosin dan MAPK menyebabkan peningkatan aktivitas sitosolik fosfolipase A2 (cPLA2). cPLA2 menghidrolisis fosfolipid dan membebaskan asam arakhidonat, sehingga menyebabkan peningkatan produksi prostaglandin melalui cyclooxygenase-1 (COX-2), sebuah enzim yang ditingkatkan oleh MAPK. Rho kinase meningkatkan fosforilasi rantai ringan pada kepala miosin (Vrachnis N et al, 2012).

Rho (Ras homology) protein adalah monomer kecil dari GTP-binding protein yang mengatur polimerisasi aktin dan fosforilasi miosin pada sel-sel otot polos (Lartey J \& Bernal AL, 2009).

Peningkatan fosforilasi rantai ringan miosin atau kekuatan kontraksi yang dipicu oleh stimulasi agonis lebih dominan dibandingkan dengan efek yang ditimbulkan dari peningkatan ion kalsium, fenomena ini disebut " $\mathrm{Ca}^{2+}$ sensitization". Rho yang telah teraktivasi meningkatkan fosforilasi rantai ringan miosin pada konsentrasi kalsium yang konstan, ini menunjukkan bahwa Rho memiliki peran pada mekanisme pengaturan " $\mathrm{Ca}^{2+}$ sensitization" (Tahara M et al, 2002). Fenomena " $\mathrm{Ca}^{2+}$ sensitization" terjadi setelah stimulasi agonis berlangsung lama dan dapat berlangsung selama beberapa jam atau bahkan beberapa hari. (Vrachnis $\mathrm{N}$ et al, 2011).

Mekanisme molekuler " $\mathrm{Ca}^{2+}$ sensitization" sampai saat ini masih sedang diteliti. Pada beberapa tipe jaringan, Rho protein memicu terjadinya " $\mathrm{Ca}^{2+}$ sensitization”. Aktivasi terjadi karena adanya stimulasi pada reseptor Ga12,13; Gaq; atau Gai, yang mengubah RhoA-GDP inaktif menjadi RhoA-GTP aktif melalui perubahan pada faktor-faktor guanin nukleotida. (Shmygol A et al, 2006). Pada saat aktivasi, RhoA-GTP berikatan dengan efektor kinase, seperti Rho kinase (ROCK) untuk mengatur kontraksi otot polos dengan cara ROCK mengaktifkan miosin otot polos melalui proses fosforilasi dan 
menghambat miosin fosfatase (Lartey $\mathbf{J} \&$ Bernal AL, 2009). Aktivasi ROCK dan proses fosforilasi miosin berlangsung secara bersamaan selama kontraksi uterus

yang dirangsang oleh oksitosin (Tahara M et al, 2002).

\section{KESIMPULAN}

Oksitosin mempengaruhi kontraksi otot polos uterus melalui mekanisme " $\mathrm{Ca}^{2+}$ dependent" dan " $\mathrm{Ca}^{2+}$ independent". Pada mekanisme " $\mathrm{Ca}^{2+}$ dependent", reseptor oksitosin pada membran otot polos akan membuka kanal ion kalsium dan natrium serta menimbulkan depolarisasi membran. Selain itu reseptor oksitosin pada membran yang tidak membuka kanal ion manapun dapat menyebabkan perubahan internal pada serabut otot, seperti pelepasan ion kalsium dari retikulum sarkoplasma intrasel, ion kalsium kemudian menginduksi terjadinya kontraksi. Sedangkan pada mekanisme " $\mathrm{Ca}^{2+}$ independent", Rho yang telah berikatan dengan ROCK mengaktifkan miosin otot polos melalui proses fosforilasi dan menghambat miosin fosfatase

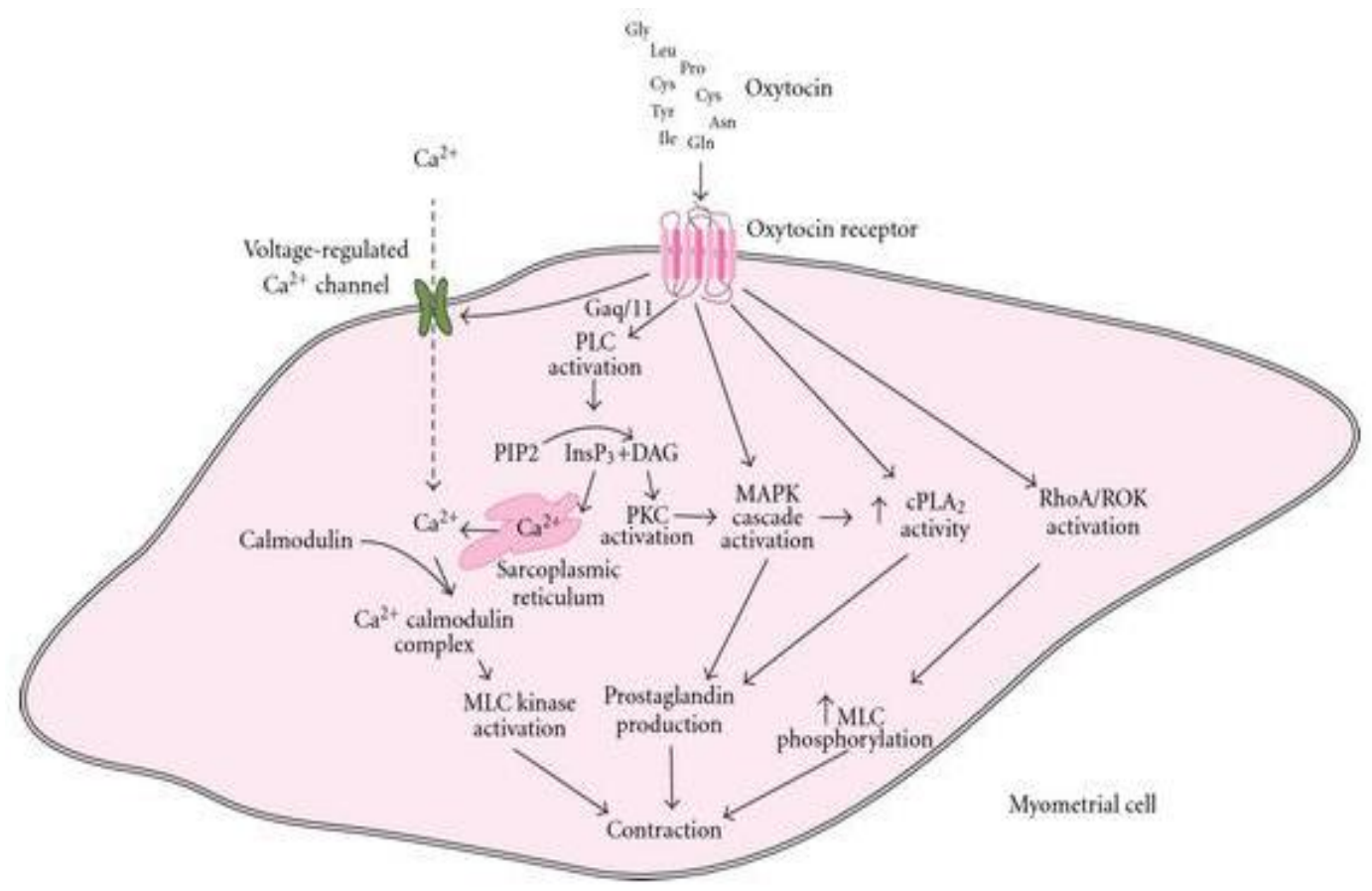

Gambar 2. Mekanisme " $\mathrm{Ca}^{2+}$ dependent" dan " $\mathrm{Ca}^{2+}$ independent" Oksitosin Pada Otot Polos Uterus

\section{DAFTA R PUSTAKA}

Guyton C \& Hall JE. 2006. Fisiologi Kedokteran. Edisi 11. EGC Jakarta

Lartey J \& Bernal AL. 2009. RHO Protein

Regulation Of Contraction In

Human Uterus. Reproduction. Vol 128. Pp 407-424

Shmygol A, Gullam J, Blanks A, and Thornton S. 2006. Multiple Mechanisms Involved In OxytocinInduced Modulation Of Myometrial
Contractility. Acta Pharmacologica Sinica. 27 (7). Pp.827-832

Tahara M et al. 2002. Rho/Rho-Kinase Cascade Is Involved In OxytocinInduced Rat Uterine Contraction. Endocrinology. 143(3). Pp 920-929

Vrachnis N, Malamas FM, Sifakis S, Deligeoroglou E, and Iliodromiti $\mathrm{Z}$. 2011. The Oxytocin-Oxytocin Receptor System and Its Antagonists as Tocolytic Agents. International Journal of 
Endocrinology. Volume 2011 (2011)

Vrachnis $\mathrm{N}$ et al. 2012. Oxytocin and Myometrial Contractility In Labor. www.intechopen.com 